\title{
Chitosan That Renewable Film and Coatings, Evaluation in Terms of Drosophila
}

\author{
Eda Güneş 1,*, Hatice Kübra Erçetin ${ }^{2}$ \\ 1 Department of Gastronomy and Culinary Arts, Faculty of Tourism, Necmettin Erbakan University, Konya, Turkey; \\ egunes@erbakan.edu.tr (E.G.); \\ 2 Department of Gastronomy and Culinary Arts, Faculty of Tourism, Necmettin Erbakan University, Konya, Turkey; \\ htk.kubra@gmail.com (H.K.E.); \\ * Correspondence: egunes@erbakan.edu.tr (E.G.);
}

Scopus Author ID 57193812931

Received: 20.05.2021; Revised: 26.06.2021; Accepted: 30.06.2021; Published: 14.08.2021

\begin{abstract}
The dried mulberry (Morus alba) is among the fruits that occurrence a high risk of storage pests due to its high sugar content. Coating materials slow down the chemical spoilage that will occur in foods. The effect of the coating material used in the study on mulberry and Drosophila melanogaster was determined. The insect's weight, texture, and biochemical analysis (Total oxidant- TOS; total antioxidant levels-TAS; oxidative stress index-OSI; Glutathione-S-transferase-GST and Catalase-CAT enzymes) were determined as a result of the application. In terms of weight, it was observed that the weight of individuals fed with $1 \%$ chitosan-coated mulberry was higher in female and male individuals. In terms of texture, the highest hardness was measured in males fed $0.2 \%$ chitosan and females fed $1 \%$ chitosan. Because of the biochemical analysis, the insect does not create resistance. The GST, CAT and TAS enzymes are synthesized close to normal. The OSI is low without increasing TOS, indicating that 1 and $2 \%$ coated mulberries are usable in environments and insects.
\end{abstract}

Keywords: Antioxidant enzyme; Drosophila melanogaster; Morus alba; Textur;, Edible coating.

(C) 2021 by the authors. This article is an open-access article distributed under the terms and conditions of the Creative Commons Attribution (CC BY) license (https://creativecommons.org/licenses/by/4.0/).

\section{Introduction}

Packages used to preserve foods can be plastic, tin, glass, cardboard, and edible films/coatings (EC) are also preferred. When these natural coatings are consumed by forming a semi-permeable membrane in products, they are said to be usable in terms of humans, nature, and the environment [1]. Polysaccharides, fat, and proteins are used as the main component in the formation of EC according to their biological resources. Although EC is highly preferable because it does not carry carcinogenic risks and does not generate waste [2], its commercial use is limited due to its poor mechanical and barrier properties [3]. Among EC, chitosan, a polysaccharide structure, is used as a coating material on many different foods [4,5].

Today, studies on the effects of foods such as EC on the environment and human beings are common. For this purpose, model organisms are used in studies to make accurate predictions about living things and the environment [6-12]. Drosophila melanogaster Meigen is among the living beings preferred in determining the effect of EC applied on foods [12]. In addition, insects, which are seen as biological contamination elements in foods, cause losses by affecting the product's taste, appearance, smell, etc., properties. In insects, besides having their defense mechanisms (antioxidant enzymes) against internal and external factors such as vertebrates, they can also develop an adaptation that can protect their generation by creating 
resistance [13]. Glutathione-S transferase enzyme (GST) and insect texture are preferred in determining resistance.

For this purpose, the mulberry (Morus alba L.), which is one of the fruits with high sugar content, was left in the nutrient medium of $D$. melanogaster by spraying with chitosan. Weight, texture, total oxidation, and antioxidant enzyme amounts were determined in the adult insects with feeding trials.

\section{Materials and Methods}

$0.2-2 \%$ chitosan (with $1 \%$ acetic acid and $0.5 \%$ glycerol) solution prepared according to the method of Carbonell-Capella et al. [14] on commercially available mulberries (M. alba); It was used by spraying [14-16]. All chemicals were supplied from Sigma-Aldrich. 0.2-2\% chitosan solution (with $1 \%$ acetic acid) was prepared by homogenization for one hour at $40^{\circ} \mathrm{C}$ and ultrasonic washing for $30 \mathrm{~min}[15,16]$. The chitosan solution was coated on the entire surface of the dried mulberry by spraying method (airbrush-Artos Power).

D. melanogaster (Oregon) culture has been grown in the laboratory of the University with an artificial diet [17] since 2014 (60-70\% humidity and $\left.25 \pm 2^{\circ} \mathrm{C}\right)$. Standard food developed by Roberts [18] is used in the nutrition of culture.

For 9 groups, 450 individuals of the same age, newly matured and unpaired, were divided into 50 individuals (female: male) in each bottle. The food was replaced every 2 days so that the dead insects were removed from the trial design and monitored for 30 days [19]. Groups; Control groups (1st group only insect, 2nd group mulberry feeding insect, 3rd glycerol coated mulberry-feeding group), group without the chitosan EC (4-6 groups) insects were feeding only $0.2-2 \%$ coating material), with the chitosan EC group (7-9 groups) Insects that feed only on mulberries covered with $0.2-2 \%$ coating material). Individuals fed only with the addition of glycerol added to insect food for control were not shown in text graphics.

Before and after the experiment, 4 females and 4 males were selected from each trial design, and their weights were weighed (Ohaus PA-214C) and their averages were taken.

For texture analysis, after obtaining permission from University Food Engineering Department, a textured device was used. Texture profile analysis (TPA) was performed on insects using a textured device (Texture Analyzer TAXT2I; stable microsystems) with at least 10 individuals each. A $5 \mathrm{~mm}$ diameter penetration probe was used for TPA; The hardness in the insect was determined as the maximum force applied in the first compression, with a loading weight of approximately $2 \mathrm{mg}$ and a distance of $0.1 \mathrm{~mm}$. Because of the 10-50\% strain penetration application, it was decided that $10 \%$ was the most suitable [20].

20 individuals switched to biochemical analysis after extraction with cold homogenization buffer in ultrasonic homogenizer [21]. By using Baran medical, Rel Assay Diagnostics Kit, Total antioxidant levels of the samples (TAS; $\mu$ mol Trolox Eq/L) at $660 \mathrm{~nm}$ (Biochrom Libra S22) using a spectrophotometer; Total oxidation levels (TOS; $\mu$ mol $\mathrm{H} 2 \mathrm{O} 2 \mathrm{Eq} / \mathrm{L}$ ) were measured at $530 \mathrm{~nm}[22,23]$. Samples were calculated based on the standard formula stated in previous studies. The TOS/TAS levels and the Oxidative stress index OSI were determined [22]. The activity determination of the catalase (Enzyme nomenclature 1.11.1.6) enzyme was made by the method developed by Aebi [24] using commercially obtained kits (Rel Assay Diagnostics, Catalase (CAT) from Baran Medical. Enzyme activity is given in units of $\mu \mathrm{mol} / \mathrm{mg}$ protein/min. The determination of glutathione-S-transferase (Enzyme nomenclature 2.5.1.18) was made according to the method developed by Habig et al. 
[25]. Enzyme activity was calculated as the amount of thioether generated per $1 \mathrm{mg}$ of total protein in the supernatant at $340 \mathrm{~nm}(340: 9.6 \mathrm{mM} / \mathrm{cm})$ for $1 \mathrm{~min}$. In addition, the specific activity of the enzyme was given as $\mu \mathrm{mol} / \mathrm{mg}$ protein $/ \mathrm{min}$.

Duncan Multiple Comparison Test was used to determine the difference between the applications in the analysis results of the samples, and the statistical package program (LSD and Duncan test) was used to determine the difference between the averages of the groups with homogeneous and normal distribution. The comparison was made using a one-way analysis of variance (ANOVA) to determine the difference between groups. Texture analysis was performed in two replications and the other experiments in three replicates, the significance of the means is shown in figures at the $0.001,0.05$, and 0.01 probability levels, and standard errors (SE) are given.

\section{Results}

The study determined the effect of the coating material by transferring the female-male individual: It was determined that the egg-laying was less, and there was no larval development on the mulberries on which the coating material was applied.

\subsection{Weight and texture analysis.}

Females fed with control food (1st group) $(1.85 \pm 0.01 \mathrm{mg})$ weigh more than males $(0.73 \pm 0.01 \mathrm{mg})$ [26-28]. When the weights of insects fed with EC mulberries (7-9 ${ }^{\text {th }}$ Group) were examined, it was observed that female individuals fed mulberries ( $8^{\text {th }}$ group) coated with $1 \%$ chitosan solution had the highest weight $(4.00 \pm 0.02 \mathrm{mg}$ ) ( Figure 1.a). The weight was found to be the lowest $(0.25 \mathrm{mg})$ in females fed with $0.2 \%$ and 1 chitosan. It was determined that individuals fed with $1 \%$ chitosan $(2.25 \pm 0.01 \mathrm{mg})$ were the heaviest in males. The bodyweight of men fed with $0.2 \%$ chitosan and the chitosan-coated product was the lowest $(0.10 \pm 0.01 \mathrm{mg})$. While the correlation was not observed between the weight of individuals and nutritional products in females, a positive correlation was observed in males due to the increasing concentration (Figure 1).

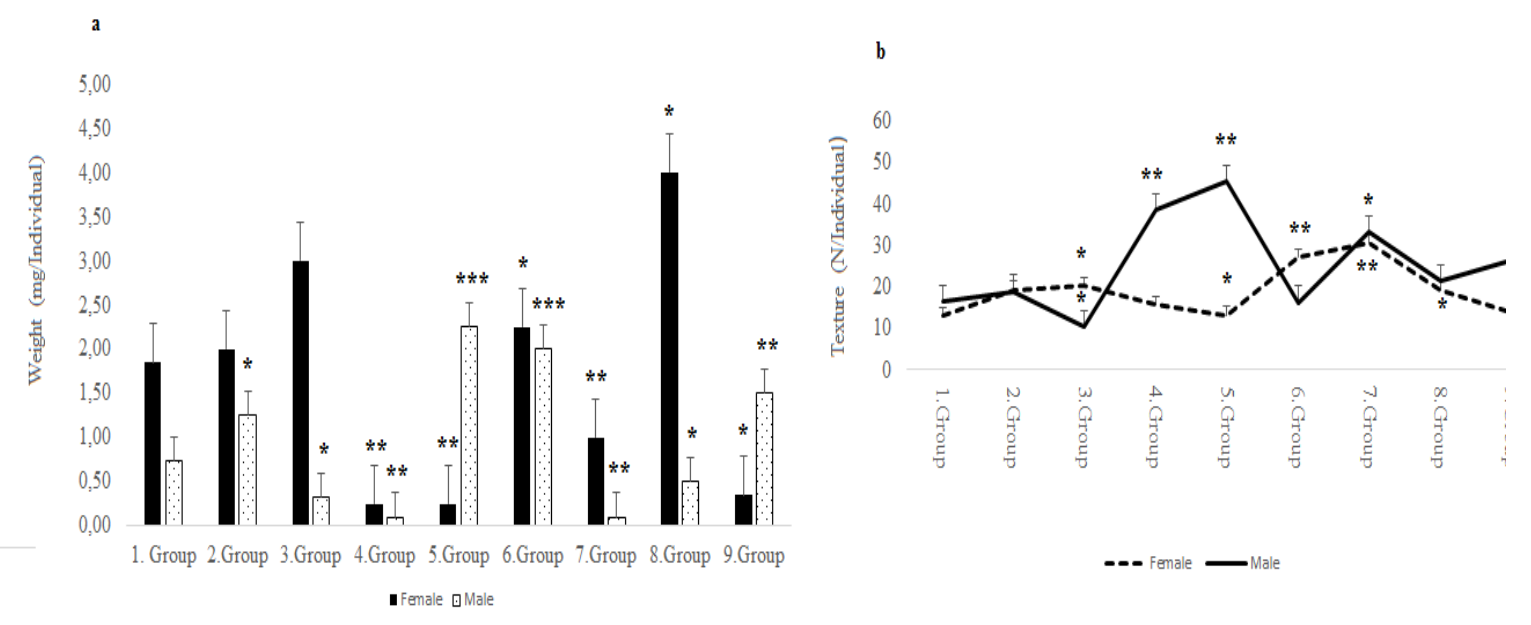

Figure 1. (a) Weight in Adult Individuals and, (b) Texture analysis $(* \mathrm{p}<0.05$, ** $\mathrm{p}<0.01$, *** $\mathrm{p}<0.001)$ According to Figure 1.b, it can be said that the most stiffness in male individuals is in individuals fed with chitosan at a rate of $1 \%(45.516 \pm 0.2 \mathrm{~N})$. In females, it was determined that the highest hardness was found in samples fed with mulberries covered with $0.2 \%$ chitosan solution $(30.574 \pm 0.2 \mathrm{~N})$. 


\subsection{Biochemical analysis.}

According to Figure 2.a, TOS activity in female individuals is measured at the same level in insects fed with EC $(0.06 \mu \mathrm{mol} / \mathrm{L})$, and the lowest level was found in insects fed with $2 \%$ chitosan solution ( $6^{\text {th }}$ group). TAS activity is highest in female individuals fed mulberries covered with chitosan solution and glycerol $(1.20 \mu \mathrm{mol} / \mathrm{L})$, it has decreased to $0.10 \mu \mathrm{mol} / \mathrm{L}$ in samples fed only with mulberry. According to the oxidative stress index, the highest stress after the control group was measured in female insects fed only mulberry $(0.92 \mu \mathrm{mol} / \mathrm{L})$. TOS activity in the male that compared to the control group (Figure 2.b) was measured highest in male individuals fed only mulberry $(2.61 \mu \mathrm{mol} / \mathrm{L})$. The lowest TOS activity is seen in male individuals $\left(6^{\text {th }}\right.$ group) fed with $2 \%$ chitosan solution $(1.30 \mu \mathrm{mol} / \mathrm{L})$. The highest TAS activity was measured in individuals fed mulberries covered with $1 \%$ chitosan solution ( $5^{\text {th }}$ group) and decreased by $1.00 \mu \mathrm{mol} / \mathrm{L}$ in individuals fed the only mulberry. According to the oxidative stress index, the highest stress was measured in male individuals ( $7^{\text {th }}$ group) fed mulberries coated with $0.2 \%$ chitosan solution $(0.81 \mu \mathrm{mol} / \mathrm{L})$. In male individuals provided with chitosan solution, stress was observed to decrease from $0.65 \mu \mathrm{mol} / \mathrm{L}$ to 0.22 according to the solution rate (Figure 2.b).
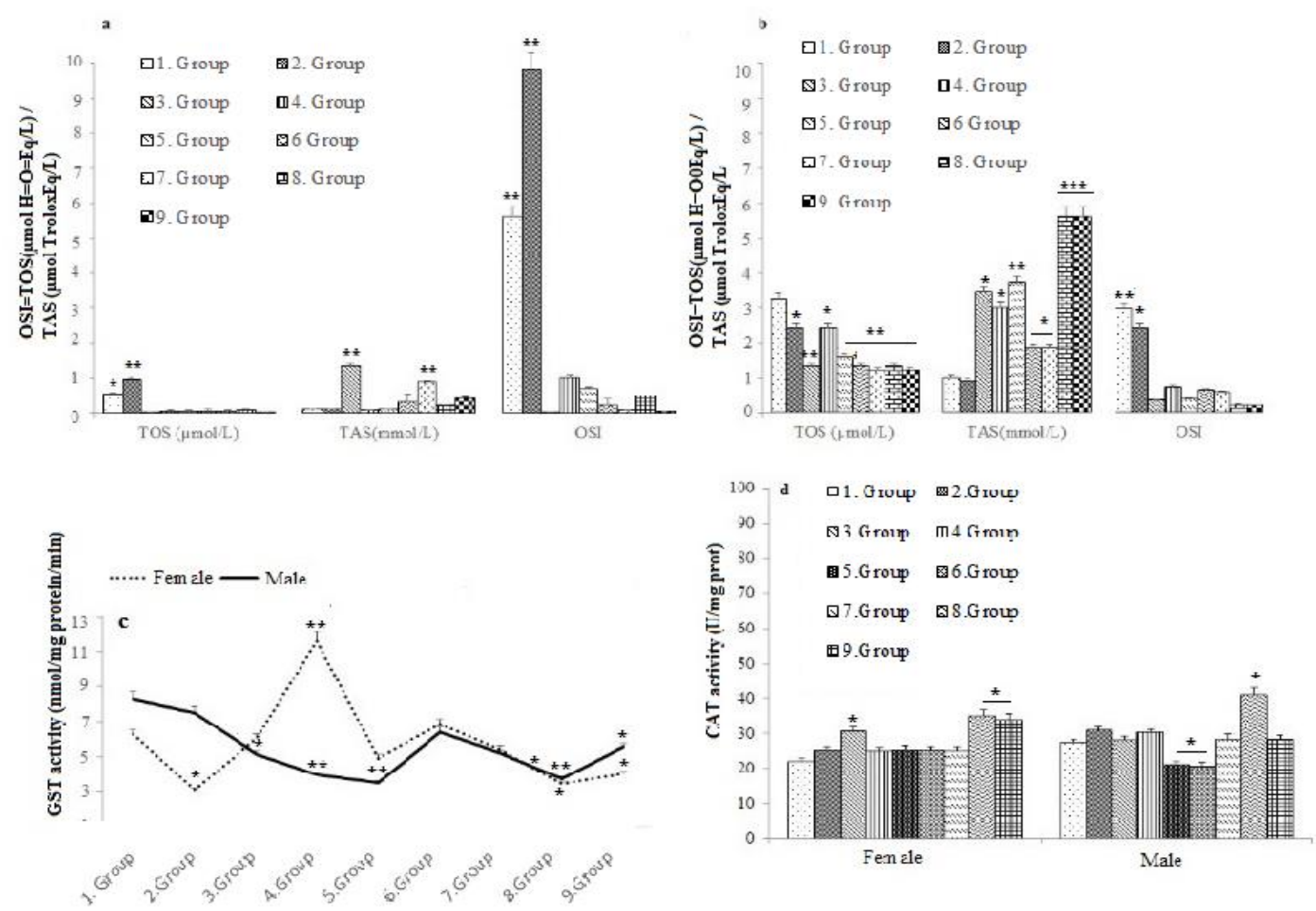

Figure 2. (a) Change of total oxidation (TOS) and total antioxidant capacity (TAS) and oxidative stress index (OSI) in female fly, (b) Change of total oxidation (TOS) and total antioxidant capacity (TAS) and oxidative stress index (OSI) in male fly, (c) Antioxidant-resistance enzyme (GST) in adult individuals of the insect, (d) Catalase enzyme (CAT) in females and males $(* \mathrm{p}<0.05 ; \mathrm{F}=3.01 * * \mathrm{p}<0.01 ; \mathrm{F}=4.72 * * * \mathrm{p}<0.001$ ) (df; 26).

Fluctuations were determined in insect resistance enzyme depending on the chitosancoating (Figure 2.c). It can be said that there is an increase $(6.03 \mu \mathrm{mol} / \mathrm{mg}$ protein $/ \mathrm{min})$ in male subjects ( $9^{\text {th }}$ group) fed mulberries covered with $2 \%$ chitosan solution compared to other samples. The highest GST activity in females was measured in insects fed with chitosan-coated mulberries ( $7^{\text {th }}$ group) at a rate of $0.2 \%$, and decreased to $2.35(\mu \mathrm{mol} / \mathrm{mg}$ protein $/ \mathrm{min}$ ) in females individuals fed the only mulberry. In males, the highest GST activity was measured in insects that only feed on mulberry $(7.29 \mu \mathrm{mol} / \mathrm{mg} / \mathrm{protein} / \mathrm{min})$. The lowest resistance in males 
was determined in insects fed with $1 \%$ chitosan-coated mulberry $(3.3 \mu \mathrm{mol} / \mathrm{mg}$ protein $/ \mathrm{min})$ (Figure 2.c). Although fluctuations are observed in the CAT enzyme activity values of the fly, there is no positive or negative correlation (Figure 2.d). It was determined that the highest CAT activity was found in insects fed with $1 \%$ chitosan-coated mulberry in females $(35.14$ $\mu \mathrm{mol} / \mathrm{mg} / \mathrm{protein} / \mathrm{min}$ ) and males $(41.01 \mu \mathrm{mol} / \mathrm{mg} / \mathrm{protein} / \mathrm{min})$ individuals (Figure 2.d ).

\section{Discussion}

Spoilage and losses have occurred on food during storage, but these situations can be reduced by appropriate storage and storage methods [29]. EC, which is a preferred method to prevent product losses; it is frequently applied to the fruits and is used to keep oxygen, carbon dioxide, and lipid passages under control, to reduce the loss of taste and aroma substances, to keep antioxidants, antimicrobial substances, pigments, ions and vitamins in the product, stopbrowning reactions in the product and to improve food quality and shelf life [30,31]. EC is used as an efficient moisture barrier to reduce water loss, especially in fresh and frozen foods [32]. Thus, the development of insects [33,34], which are important storage pests, can be limited in products stored where warehouses with moisture content below 10\% [29]. Water-dependent and independent quality of life may change in insects [35]. The product may cause the insect's negative effect on larval nutrition and development with reduced moisture of the EC applied on the mulberryBecause the hardness of the fed product can change the feeding behavior of the insect [36]. D.melanogaster is widely used as a model to study obesity, metabolic syndrome, diabetes, dietary cardiovascular diseases, and others [37-41]. Insects are models that do not require ethics and can be followed up quickly to evaluate their feeding habits and understand their metabolic and genetic mechanisms. Nutrition is associated with growth development, longevity, and chitin synthesis by affecting metabolism [42]. Because the fly changes the synthesis of chitin against the nutrient components and the environment, this causes an increase or decrease in its hardness [12, 42-44]. For this reason, the EC used in the study causes changes in the external tissue structure during nutrition (Figure 1; $\mathrm{p}<0.001$ ): In the study, it was determined that the stiffness in female individuals approached the normal level with the proportional increase of EC, and there was a disproportionate increase and decrease in hardness in male flies (Figure 1). Chitosan-coated Ahlat has increase fly hardness [36], which supports the decrease seen in the texture of the female individuals in the study. The source of sugar taken in the diet, nutritional components, or hunger is affected by the insect's weight $[34,35]$. The study determined that females were heavier than males and females were harder in texture (Figure 1). As the weight increases, the texture increases in direct proportion. According to the microscopic observations made, it is thought that the increased hardness in the female fly is due to the effect of the egg-laying tube and the inability to lay eggs. In males, weight gain was the most in those fed with $2 \%$ EC with increasing concentrations ( $9^{\text {th }}$ group). Thus, EC reduces reproduction, but studies also support the insect's effects on the living creature, depending on the OSI results $[12,45,46]$.

Macromolecules such as protein, fat, carbohydrate taken in the diet; body size is important in terms of viability, the oxidant mechanism that develops due to aging and nutrition $[27,47-50,34]$. Insects have oxidized substances that cause Reactive Oxygen Species formation thanks to their metabolism or nutritional content to survive in an unsuitable environment with the same mechanism [51-53]. Because antioxidants in products consumed in the diet are important factors for human health, target/non-target organisms and fruit quality. Eukaryotic organisms have an antioxidant enzyme system to protect them from the harmful effects of 
oxidative radicals [54-57]. While the calorie restriction decreases the insect's weight, it extends the life span and increases the antioxidant enzymes [58, 21]. GST is expressed as a defense system that includes enzymatic and nonenzymatic antioxidants. Antioxidant and GST enzyme activities are higher in men than in women [34]. However, in male male individuals in the study, nutritional resistance was reduced with coated mulberries, and resistance returned to normal values in EC mulberries with $2 \%$ chitosan solution (Figure 2; $9^{\text {th }}$ group). However, feeding mulberry with $0.2 \%$ coated mulberry $\left(7^{\text {th }}\right.$ group) shows that it can be used for storage pests (target) because feeding females increase resistance [59]. We should say that the use of small amounts of YK applied for non-target organisms is not appropriate. In addition, the female flies that consume more food than males are more prone to ATP consumption during lipogenesis, which is protection against calorie overload [38]. It suggests that GST enzyme activities are more affected.

Examination of CAT activity in 10-day-old adults in the study is due to the antioxidant enzyme and expresses the insect's response to dietary oxidation with nutrition and aging. Although CAT activity increased in female individuals fed mulberries with YK, a decrease in the same activity was determined in male individuals (Figure 2). A study conducted with $M$. oleifera leaf extract stated that the insect significantly increased its GST and CAT activities, while its SOD and malondialdehyde activity decreased [60]. Instead of evaluating a single antioxidant against stress, the stress response is calculated according to OSI by using the TOSTAS mechanism [50]. The study determined that TOS activity was the lowest in female individuals, and the highest TAS activity (excluding the glycerol group) was found in insects fed with $2 \%$ chitosan solution (6th group). In male individuals, $2 \%$ chitosan coating ( $6^{\text {th }}$ group; $\mathrm{p}<0.001$ ) has the opposite effect of females. The TAS activity of male subjects (group 8) fed with mulberries coated with $1 \%$ chitosan solution was the highest. A decrease in stress (OSI) was observed in female and male adults fed with mulberries $\left(9^{\text {th }}\right.$ group) with $2 \%$ EC coated.

\section{Conclusions}

The closest texture analysis of mature insects fed with mulberries covered with 1 and $2 \%$ has enabled us to determine the EC as the most appropriate usage rate for flies. This result shows that the use of chitosan as a coating material in dried and sugary fruits is suitable for nature-environment-non-target organisms. In addition, it is thought that low EC can be used to reduce the reproduction of the pest that is seen as a target.

\section{Funding}

This research received no external funding, except for University Research Projects (only materials).

\section{Acknowledgments}

This research was technical support by Necmettin Erbakan University Scientific Research Projects (191322005).

\section{Conflicts of Interest}

The authors declare no conflict of interest. 


\section{References}

1. Erge, A.; Eren, Ö. Effect of gelatin/chitosan coating on chicken patty quality during frozen storage: a response surface methodology application. Kafkas Universitesi Veteriner Fakultesi Dergisi 2021, 27, 165-171, https://doi.org/10.9775/kvfd.2020.24949.

2. Akbaba G. Yenilebilir ambalajlar. Bilim ve Teknik Dergisi 2006, 30-32.

3. Azeredo, H.M.; Mattoso, L.H.C.; Wood D.; Williams T.G.; Avena-Bustillos R.J.; McHugh T.H. Nanocomposite edible films from mango puree reinforced with cellulose naonofibers. Journal of Food Science 2009, 74, N31-N35, https://doi.org/10.1111/j.1750-3841.2009.01186.x.

4. Suyatma, N.E.; Tighzert, L.; Copinet, A.; Coma, V. Effects of hydrophilic plasticizers on mechanical, thermal, and surface properties of chitosan films. Journal of Agricultural and Food Chemistry 2005, 53, 3950-3957, https://doi.org/10.1021/jf048790+.

5. Coban, O.E.; Inanlı, A.G.; Celik, B.; Yüce, S. Gökkuşağı alabalığı (oncorhynchus mykiss, walbaum 1792) filetolarının muhafazası sırasında kimyasal ve duyusal kalitesi üzerinde doğal koruyucu maddelerle zenginleştirilmiş kitosan yenilebilir kaplamaların etkileri. Ecological Life Sciences 2018, 13, 182-191.

6. Cao, Y.; Zhao, M.; Ma, X.; Song, Y.; Zuo, S.; Li, H.; Deng, W. A critical review on the interactions of microplastics with heavy metals: Mechanism and their combined effect on organisms and humans. Science of The Total Environment 2021, 147620, https://doi.org/10.1016/j.scitotenv.2021.147620.

7. Safari, Z.S.; Ding, P.; Atif, A.; Salari, M.W.; Yusoff, S.F. Antifungal evaluation of edible coating agent against fusarium oxysporum on tomato. International Journal of Scientific \& Technology Research 2021, 2 , 51-62.

8. Riaz, A.; Aadil, R.M.; Amoussa, A.M.O.; Bashari, M.; Abid, M.; Hashim, M.M. Application of chitosanbased apple peel polyphenols edible coating on the preservation of strawberry (Fragaria ananassa cv Hongyan) fruit. Journal of Food Processing and Preservation 2021, 45, 1, e15018, https://doi.org/10.1111/jfpp.15018.

9. Zhelyazkov, S.; Ivanova, P. Microbiological parameters during storage of minimally processed melons with and without edible coating. Bulgarian Chemical Communications 2021, 91, https://doi.org/10.34049/bcc.53.1.5325.

10. Kocira, A.; Kozłowicz, K.; Panasiewicz, K.; Staniak, M.; Szpunar-Krok, E.; Hortyńska, P. Polysaccharides as Edible Films and Coatings: Characteristics and influence on fruit and vegetable quality-A Review. Agronomy 2021, 11, 813, https://doi.org/10.3390/agronomy11050813.

11. Jafarzadeh, S.; Nafchi, A.M.; Salehabadi, A.; Oladzad-Abbasabadi, N.; Jafari, S.M. Application of bionanocomposite films and edible coatings for extending the shelf life of fresh fruits and vegetables. Advances in Colloid and Interface Science 2021, 102405, https://doi.org/10.1016/j.cis.2021.102405.

12. Güneş, E.; Sert, D., Erçetin, H.K. Bal mumu ve propolis gibi kaplama ürünlerinin böcekteki etkisinin belirlenmesi. Ĭgdır Üniversitesi Fen Bilimleri Enstitüsü Dergisi 2019, 9, 2133-2139, https://doi.org/10.21597/jist.524599.

13. Gao, Y.; Kim, J.H.; Jeong, I.H.; Clark, J.M.; Lee, S.H. Transcriptomic identification and characterization of genes commonly responding to sublethal concentrations of six different insecticides in the common fruit fly, Drosophila melanogaster. Pesticide Biochemistry and Physiology 2021, 104852, https://doi.org/10.1016/j.pestbp.2021.104852.

14. Carbonell-Capella, J.M.; Buniowska, M.; Esteve, M.J.; Frígola, A. Effect of Stevia rebaudiana addition on bioaccessibility of bioactive compounds and antioxidant activity of beverages based on exotic fruits mixed with oat following simulated human digestion. Food Chemistry 2015, 184, 122-130, https://doi.org/10.1016/j.foodchem.2015.03.095.

15. Sezer, Y.Ç.S.; Bozkurt, H. Et ve et ürünlerinin üretimi ve saklanmasında antimikrobiyal ambalajlama sistemlerinin kullanım1. Food and Health 2021, 7, 150-163, https://doi.org/10.3153/FH21016.

16. Simşek, T.; Keyf, S. Alginat-kitosan bazlı biofilm sentezi için deneysel tasarım uygulaması. Karaelmas Fen ve Mühendislik Dergisi 2018, 8, 482-490.

17. Rogina, B.; Helfand, S.L. Cu, Zn superoxide dismutase deficiencyaccelerates the time course of an agerelated markerin Drosophila melanogaster. Biogerontology 2000, 1, 163-169, https://doi.org/10.1023/A:1010039813107.

18. Roberts, S.J. Veterinary obstetrics and genital diseases. Theriogenology 1986.

19. Videlier, M.; Careau, V.; Wilson, A.J.; Rundle, H.D. Quantifying selection on standard metabolic rate and body mass in Drosophila melanogaster. Evolution 2021, 75, 130-140, https://doi.org/10.1111/evo.14126. 
20. Güneş, E.; Sert, D. Borik asit'in farklı gelişim evrelerindeki Drosophila melonagaster'in dış iskeleti üzerine etkisi. Tarim ve Doga Dergisi 2018, 21, 126.

21. Güneş, E. Antioxidant effects of ankaferd blood stopper doped polyvinyl pyrolidon in an experimental model created in insect. Food and Chemical Toxicology 2021, 148, 111935 , https://doi.org/10.1016/j.fct.2020.111935.

22. Erel, O. A new automated colorimetric method for measuring total oxidant status. Clinical Biochemistry 2005, 38, 1103-1111, https://doi.org/10.1016/j.clinbiochem.2005.08.008.

23. Ozgün, E.; Ozgün, G.S.; Eskiocak, S.; Yalçın, O.; Gökmen, S.S. Deneysel kolitte L-karnitinin serum paraoksonaz, arilesteraz ve laktonaz aktivitelerine ve oksidatif duruma etkisi. Turkish Journal of Biochemistry 2013, 38, 145-153.

24. Aebi, H. Catalase in vitro. Methods in Enzymology. L. Packer ed.; Academic Press: Orlando, FL, USA, 1984; 121-126.

25. Habig, W.H.; Pabst, M.J.; Jakoby, W.B. Glutathione S-transferases: the first enzymatic step in mercapturic acid formation. Journal of Biological Chemistry 1974, 249, 7130-7139, https://doi.org/10.1016/S00219258(19)42083-8.

26. Kearsey, M.J.; Kojima, K.I. The genetic architecture of body weight and egg hatchability in Drosophila melanogaster. Genetics 1967, 56, 23.

27. De Moed, G.H.; Kruitwagen, C.L.J.J.; De Jong, G.; Scharloo, W. Critical weight for the induction of pupariation in Drosophila melanogaster: genetic and environmental variation. Journal of Evolutionary Biology 1999, 12, 852-858, https://doi.org/10.1046/j.1420-9101.1999.00103.x.

28. Mirth, C.; Truman, J.W.; Riddiford, L.M. The role of the prothoracic gland in determining critical weight for metamorphosis in Drosophila melanogaster. Current Biology 2005, 15, 1796-1807, https://doi.org/10.1016/j.cub.2005.09.017.

29. Kibar, H.; Oztürk, T.; Esen, B. The effect of moisture content on physical and mechanical properties of rice (Oryza sativa L.). Spanish Journal of Agricultural Research 2010, 3, 741-749.

30. Salgado, P.R.; Di Giorgio, L.; Musso, Y.S.; Mauri, A.N. Recent developments in smart food packaging focused on biobased and biodegradable polymers. Frontiers in Sustainable Food Systems 2021, 5, 125, https://doi.org/10.3389/fsufs.2021.630393.

31. Riaz, A.; Aadil, R.M.; Amoussa, A.M.O.; Bashari, M.; Abid, M.; Hashim, M.M. Application of chitosanbased apple peel polyphenols edible coating on the preservation of strawberry (Fragaria ananassa cv Hongyan) fruit. Journal of Food Processing and Preservation 2021, 45, e15018, https://doi.org/10.1111/jfpp.15018.

32. Kader, A.A. Ethylene-induced senescence and physiological disorders in harvested horticultural crops. HortScience 1985, 20, 54-57.

33. Fallik, E.; Perzelan, Y.; Alkalai-Tuvia, S.; Nemny-Lavy, E.; Nestel, D. Development of cold quarantine protocols to arrest the development of the Mediterranean fruit fly (Ceratitis capitata) in pepper (Capsicum annuum L.) fruit after harvest. Postharvest Biology and Technology 2012, 70, 7-12, https://doi.org/10.1016/j.postharvbio.2012.03.004.

34. Rovenko, B.M.; Kubrak, O.I.; Gospodaryov, D.V.; Perkhulyn, N.V.; Yurkevych, I.S.; Sanz, A.; Lushchak, V.I. High sucrose consumption promotes obesity whereas its low consumption induces oxidative stress in Drosophila melanogaster. Journal of Insect Physiology 2015, 79, 42-54, https://doi.org/10.1016/j.jinsphys.2015.05.007.

35. Dam, G.; Sønderholm, M.; Sørensen, E.V. Pliocene-Pleistocene megafloods as a mechanism for Greenlandic megacanyon formation: COMMENT. Geology 2020, 48, e511-e511, https://doi.org/10.1130/G48099C.1.

36. Güneş, E. Ahlat ve böcekte kitosan ile kaplamanın etkisinin belirlenmesi. Kahramanmaraş Sütçü Imam Universitesi Tarım ve Doğa Dergisi 2020, 23, 1449-1455, https://doi.org/10.18016/ksutarimdoga.vi.707642.

37. Musselman, L.P.; Fink, J.L.; Narzinski, K.; Ramachandran, P.V.; Hathiramani, S.S.; Cagan, R.L.; Baranski, T.J. A high-sugar diet produces obesity and insulin resistance in wild-type Drosophila. Disease Models \& Mechanisms 2011, 4, 842-849, https://doi.org/10.1242/dmm.007948.

38. Musselman, L.P.; Fink, J.L.; Ramachandran, P.V.; Patterson, B.W.; Okunade, A.L.; Maier, E.; Baranski, T.J. Role of fat body lipogenesis in protection against the effects of caloric overload in Drosophila. Journal of Biological Chemistry 2013, 288, 8028-8042, https://doi.org/10.1074/jbc.M112.371047.

39. Morris, A.P.; Voight, B.F.; Teslovich, T.M.; Ferreira, T.; Segrè, A.V.; Steinthorsdottir, V.; Strawbridge, R.J.; Khan, H.; Grallert, H.; Mahajan, A.; Prokopenko, I.; Kang, H.M.; Dina, C.; Esko, T.; Fraser, R.M.; Kanoni, S.; Kumar, A.; Lagou, V.; Langenberg, C.; Luan, J.a.; Lindgren, C.M.; Müller-Nurasyid, M.; Pechlivanis, S.; 
Rayner, N.W.; Scott, L.J.; Wiltshire, S.; Yengo, L.; Kinnunen, L.; Rossin, E.J.; Raychaudhuri, S.; Johnson, A.D.; Dimas, A.S.; Loos, R.J.F.; Vedantam, S.; Chen, H.; Florez, J.C.; Fox, C.; Liu, C.-T.; Rybin, D.; Couper, D.J.; Kao, W.H.L.; Li, M.; Cornelis, M.C.; Kraft, P.; Sun, Q.; van Dam, R.M.; Stringham, H.M.; Chines, P.S.; Fischer, K.; Fontanillas, P.; Holmen, O.L.; Hunt, S.E.; Jackson, A.U.; Kong, A.; Lawrence, R.; Meyer, J.; Perry, J.R.B.; Platou, C.G.P.; Potter, S.; Rehnberg, E.; Robertson, N.; Sivapalaratnam, S.; Stančáková, A.; Stirrups, K.; Thorleifsson, G.; Tikkanen, E.; Wood, A.R.; Almgren, P.; Atalay, M.; Benediktsson, R.; Bonnycastle, L.L.; Burtt, N.; Carey, J.; Charpentier, G.; Crenshaw, A.T.; Doney, A.S.F.; Dorkhan, M.; Edkins, S.; Emilsson, V.; Eury, E.; Forsen, T.; Gertow, K.; Gigante, B.; Grant, G.B.; Groves, C.J.; Guiducci, C.; Herder, C.; Hreidarsson, A.B.; Hui, J.; James, A.; Jonsson, A.; Rathmann, W.; Klopp, N.; Kravic, J.; Krjutškov, K.; Langford, C.; Leander, K.; Lindholm, E.; Lobbens, S.; Männistö, S.; Mirza, G.; Mühleisen, T.W.; Musk, B.; Parkin, M.; Rallidis, L.; Saramies, J.; Sennblad, B.; Shah, S.; Sigurðsson, G.; Silveira, A.; Steinbach, G.; Thorand, B.; Trakalo, J.; Veglia, F.; Wennauer, R.; Winckler, W.; Zabaneh, D.; Campbell, H.; van Duijn, C.; Uitterlinden, A.G.; Hofman, A.; Sijbrands, E.; Abecasis, G.R.; Owen, K.R.; Zeggini, E.; Trip, M.D.; Forouhi, N.G.; Syvänen, A.-C.; Eriksson, J.G.; Peltonen, L.; Nöthen, M.M.; Balkau, B.; Palmer, C.N.A.; Lyssenko, V.; Tuomi, T.; Isomaa, B.; Hunter, D.J.; Qi, L.; Shuldiner, A.R.; Roden, M.; Barroso, I.; Wilsgaard, T.; Beilby, J.; Hovingh, K.; Price, J.F.; Wilson, J.F.; Rauramaa, R.; Lakka, T.A.; Lind, L.; Dedoussis, G.; Njølstad, I.; Pedersen, N.L.; Khaw, K.-T.; Wareham, N.J.; Keinanen-Kiukaanniemi, S.M.; Saaristo, T.E.; Korpi-Hyövälti, E.; Saltevo, J.; Laakso, M.; Kuusisto, J.; Metspalu, A.; Collins, F.S.; Mohlke, K.L.; Bergman, R.N.; Tuomilehto, J.; Boehm, B.O.; Gieger, C.; Hveem, K.; Cauchi, S.; Froguel, P.; Baldassarre, D.; Tremoli, E.; Humphries, S.E.; Saleheen, D.; Danesh, J.; Ingelsson, E.; Ripatti, S.; Salomaa, V.; Erbel, R.; Jöckel, K.-H.; Moebus, S.; Peters, A.; Illig, T.; de Faire, U.; Hamsten, A.; Morris, A.D.; Donnelly, P.J.; Frayling, T.M.; Hattersley, A.T.; Boerwinkle, E.; Melander, O.; Kathiresan, S.; Nilsson, P.M.; Deloukas, P.; Thorsteinsdottir, U.; Groop, L.C.; Stefansson, K.; Hu, F.; Pankow, J.S.; Dupuis, J.; Meigs, J.B.; Altshuler, D.; Boehnke, M.; McCarthy, M.I.; the, D.G.R.; Meta-analysis, C.; Wellcome Trust Case Control, C.; Meta-Analyses of, G.; Insulin-related traits Consortium, I.; Genetic Investigation of, A.T.C.; Asian Genetic Epidemiology Network-Type 2 Diabetes, C.; South Asian Type 2 Diabetes, C. Large-scale association analysis provides insights into the genetic architecture and pathophysiology of type 2 diabetes. Nat. Genet. 2012, 44, 981-990, http://www.nature.com/doifinder/10.1038/ng.2383.

40. Matzkin, L.M.; Johnson, S.; Paight, C.; Markow, T.A. Preadult parental diet affects offspring development and metabolism in Drosophila melanogaster.PloS one 2013,8, e59530, https://doi.org/10.1371/journal.pone.0059530.

41. Nässel, D.R.; Kubrak, O.A.; Liu, Y.; Luo, J.; Lushchak, O.V. Factors that regulate insulin producing cells and their output in Drosophila.Frontiers in Physiology 2013, 4, 252, https://doi.org/10.3389/fphys.2013.00252.

42. Moussian, B.; Schwarz, H.; Bartoszewski, S.; Nüsslein-Volhard, C. Involvement of chitin in exoskeleton morphogenesis in Drosophila melanogaster. Journal of Morphology 2005, 264, 117-130, https://doi.org/10.1002/jmor.10324.

43. Shao, Z.M.; Ding, J.H.; Jiang, D.L.; Liu, Z.X.; Li, Y.J.; Wang, J.; Wang, J.; Sheng, S.; Wu, F.A. Characterization and Functional Analysis of trehalase Related to Chitin Metabolism in Glyphodes pyloalis Walker (Lepidoptera: Pyralidae). Insects 2021, 12, 370, https://doi.org/10.3390/insects12040370.

44. Zhang, X.; Yuan, J.; Li, F.; Xiang, J. Chitin synthesis and degradation in crustaceans: a genomic view and application. Marine Drugs 2021, 19, 153, https://doi.org/10.3390/md19030153.

45. Swoboda-Bhattarai, K.A.; Burrack, H.J. Influence of edible fruit coatings on Drosophila suzukii (Matsumura)(Diptera: Drosophilidae) oviposition and development. International Journal of Pest Management 2014, 60, 279-286, https://doi.org/10.1080/09670874.2014.971453.

46. Iniesto, M.; Gutiérrez-Silva, P.; Dias, J.J.; Carvalho, I.S.; Buscalioni, A.D.; López-Archilla, A.I. Soft tissue histology of insect larvae decayed in laboratory experiments using microbial mats: Taphonomic comparison with Cretaceous fossil insects from the exceptionally preserved biota of Araripe, Brazil. Palaeogeography, Palaeoclimatology, Palaeoecology 2021, 564, 110156, https://doi.org/10.1016/j.palaeo.2020.110156.

47. Kawamura, K.; Shibata, T.; Saget, O.; Peel, D.; Bryant, P.J. A new family of growth factors produced by the fat body and active on Drosophila imaginal disc cells. Development 1999, 126, 211-219, https://doi.org/10.1242/dev.126.2.211.

48. Mair, W.; Piper, M.D.; Partridge, L. Calories do not explain extension of life span by dietary restriction in Drosophila. PLoS Biol 2005, 3, e223, https://doi.org/10.1371/journal.pbio.0030223. 
49. Khalily, M.A.; Ustahuseyin, O.; Garifullin, R.; Genc, R.; Guler, M.O. A supramolecular peptide nanofiber templated Pd nanocatalyst for efficient Suzuki coupling reactions under aqueous conditions. Chemical Communications 2012, 48, 11358-11360, https://doi.org/10.1039/C2CC36228G.

50. Güneş, E. Besinler ve beslenme çalışmalarında Drosophila. Kahramanmaraş Sütçü Imam Universitesi Doğa Bilimleri Dergisi 2016, 19, 4894-4955.

51. Sun, W.; Meng, Z.; Li, R.; Zhang, R.; Jia, M.; Yan, S.; Zhu, W. Joint effects of microplastic and dufulin on bioaccumulation, oxidative stress and metabolic profile of the earthworm (Eisenia fetida). Chemosphere 2021, 263, 128171, https://doi.org/10.1016/j.chemosphere.2020.128171.

52. Felton, G.W.; Summers, C.B. Antioxidant systems in insects. Archives of Insect Biochemistry and Physiology 1995, 29, 187-197, https://doi.org/10.1002/arch.940290208.

53. Hyršl, P.; Büyükgüzel, E.; Büyükgüzel, K. The effects of boric acid-induced oxidative stress on antioxidant enzymes and survivorship in Galleria mellonella. Archives of Insect Biochemistry and Physiology 2007, 66, 23-31, https://doi.org/10.1002/arch.20194.

54. Vontas, J.G.; Small, G.J.; Hemingway, J. Glutathione S-transferases as antioxidant defence agents confer pyrethroid resistance in Nilaparvata lugens. Biochemical Journal 2001,357, 65-72, https://doi.org/10.1042/bj3570065.

55. Missirlis, F.; Rahlfs, S.; Dimopoulos, N.; Bauer, H.; Becker, K.; Hilliker, A.; Jäckle, H. A putative glutathione peroxidase of Drosophila encodes a thioredoxin peroxidase that provides resistance against oxidative stress but fails to complement a lack of catalase activity. Biological Chemistry 2003, 384, 463-472, https://doi.org/10.1515/BC.2003.052.

56. Enayati, A.A.; Ranson, H.; Hemingway, J. Insect glutathione transferases and insecticide resistance. Insect Molecular Biology 2005, 14, 3-8, https://doi.org/10.1111/j.1365-2583.2004.00529.x.

57. Krishnan, N.; Kodrík, D. Antioxidant enzymes in Spodoptera littoralis (Boisduval): are they enhanced to protect gut tissues during oxidative stress? Journal of Insect Physiology 2006, 52, 11-20, https://doi.org/10.1016/j.jinsphys.2005.08.009.

58. Sohal, R.S.; Weindruch, R. Oxidative stress, caloric restriction, and aging. Science 1996, 273, 59-63, https://doi.org/10.1126/science.273.5271.59.

59. Kazemeini, H.; Azizian, A.; Adib, H. Inhibition of Listeria monocytogenes growth in turkey fillets by alginate edible coating with Trachyspermum ammi essential oil nano-emulsion. International Journal of Food Microbiology 2021, 344, 109104, https://doi.org/10.1016/j.ijfoodmicro.2021.109104.

60. Mabrouki, L.; Rjeibi, I.; Taleb, J.; Zourgui, L. Cardiac ameliorative effect of Moringa oleifera leaf extract in high-fat diet-induced obesity in rat model.BioMed Research International 2020, https://doi.org/10.1155/2020/6583603. 